\title{
THE THEOLOGY OF THE CROSS AS THEOLOGY OF THE TRINITY: A CRITIQUE OF JÜRGEN MOLTMANN'S STAUROCENTRIC TRINITARIANISM
}

\author{
Dennis W. Jowers
}

\begin{abstract}
Summary
Jürgen Moltmann consistently portrays Christ's death and resurrection as a deadly dialectic between Father, Son, and Spirit which, in his view, constitutes the decisive revelation of the divine Trinity. The idea of the Trinity which Moltmann derives from these events, however, undermines central doctrines of Christianity: specifically, the permanence of God's triunity; his impassibility and immutability; and the distinction between Christ's two natures. By denying these doctrines, Moltmann defeats his efforts to restore the Trinity to the centre of Christian theology and to construct a theodicy adequate to the dispute between Christianity and protest atheism.
\end{abstract}

\section{Introduction}

'The theology of the cross must be the doctrine of the Trinity and the doctrine of the Trinity must be the theology of the cross.' 1 This maxim captures the pith of Jürgen Moltmann's doctrine of the Trinity as expressed in The Crucified God. For Moltmann, 'the material principle of the doctrine of the Trinity is the cross of Christ. The formal principle of knowledge of the cross is the doctrine of the

1 Jürgen Moltmann, The Crucified God (tr. John Bowden \& R.A. Wilson; London: SCM, 1974), 241. One should not infer from Moltmann's use of the phrase 'theology of the cross' any real similarity between his theology and the theology of Martin Luther. Cf. Burnell F. Eckardt Jr.'s orthodox Lutheran critique of Moltmann, 'Luther and Moltmann: The Theology of the Cross', Concordia Theological Quarterly 49 (1985) 19-28. 
Trinity.'2 While Moltmann in his later works, such as The Trinity and the Kingdom of God, supplements 'the unitary testimony of the cross' 3 with other grounds for Trinitarian doctrine, even there (and in his more recent works) 'The cross is at the centre of the Trinity.'4 Moltmann, therefore, consistently maintains throughout his corpus that 'the shortest expression of the doctrine of the Trinity is the divine act of the cross, in which the Father allows the Son to sacrifice himself through the Spirit.' 5

More specifically, Moltmann holds that:

the form of the Trinity which is revealed in the giving up of the Son (i.e. the cross) appears as follows: (1) the Father gives up his own Son to death in its most absolute sense, for us; (2) the Son gives himself up, for us; (3) the common sacrifice of the Father and the Son comes about through the Holy Spirit, who joins and unites the Son in his forsakenness with the Father. ${ }^{6}$

In the following pages, we shall attempt to explore the content and consequences of this approach to the doctrine of the Trinity for the Church's understanding of the Father, Son, and Holy Ghost.

\section{The Father as Divine Executioner?}

We place the Father at the head of our analysis not only because of his status as principium sine principio, but also because Moltmann's understanding of how the Father distinguishes himself from the Son in the crucifixion has aroused more heated criticism than perhaps any other element in his theology. He writes, in an infamous passage, which he quotes from W. Popkes:

That God delivers up his Son is one of the most unheard-of statements in the New Testament. We must understand 'deliver up' in its full sense and not water it down to mean 'send' or 'give.' What happened here is what Abraham did not need to do to Isaac (cf. Rom 8:32): Christ was quite deliberately abandoned by the Father to the fate of death: God subjected him to the power of corruption, whether this be called man or death. To express the idea in its most acute form, one might say in the words of the dogma of the early church: the first person of the Trinity casts out

2 Moltmann, Crucified God, 241. Cf. Pinchas Lapide \& Jürgen Moltmann, Jewish Monotheism and Christian Trinitarian Doctrine (tr. Leonard Swidler; Philadelphia: Fortress, 1981), 47.

3 Moltmann, Crucified God, 241.

4 Moltmann, The Trinity and the Kingdom of God (tr. Margaret Kohl; London: SCM, 1981), 83.

5 Moltmann, Crucified God, 241.

6 Moltmann, Trinity, 83. 
and annihilates the second...A theology of the cross cannot be expressed more radically than it is here. ${ }^{7}$

This 'radicality' does not impress critics of Moltmann's theology who rightly accuse him of attributing to God injustice and even brutality. ${ }^{8}$ Conceiving, as he does, of God as three distinct subjects, ${ }^{9}$ he seems to claim that the Father allows the death of an innocent and, to a degree at least, unwilling, ${ }^{10}$ victim and that his onlybegotten Son.

Traditional Trinitarian theology, of course, avoids this kind of difficulty by moderating the Father-Son dialectic in the event of the cross. Even if the Father 'spared not his own Son, but delivered him up' (Rom. 8:32) to the most shameful and agonising of deaths, one cannot, because of the Father's and Son's numerical unity of essence, accuse him of inflicting torment on anyone (i.e. any essence) but himself. 'Truly himself God, himself priest, himself victim, he made satisfaction for himself, of himself, to himself.'11 Such a view makes the atonement not a pouring out of the Father's wrath on an innocent, unwilling victim, but an act of God's supremely generous virtue, satisfying divine justice and procuring divine mercy and thus reconciling righteousness and peace (Ps. 85:10; cf. Rom. 3:26).

By treating God as a single substance, the old orthodoxy ${ }^{12}$ does not, however, commit itself to an incarnation of all three Persons. For

7 Moltmann, Crucified God, 241

8 John J. O'Donnell in his Trinity and Temporality (Oxford: OUP, 1983), 154, quotes Dorothy Sölle: 'The author is fascinated by the brutality of his God. This kind of "radicality" is certainly not verbally accepted by Moltmann, but in substance it is retained and deepened. Of course he attributes the death to the "pain" of the Father who hands over the Son but it is the "will" of the Father not to spare the Son, and thus the Trinity is so constituted that the first person "annihilates" the second. The story of the sacrifice of Isaac is then not the human overcoming of an earlier level of religiosity, which could satisfy the divinity only with human sacrifices, but the unfulfilled first stage, in which the full severity of this theology of the cross was not yet reached. Only the Trinity brings God to his concept; that of the annihilator.'

9 Moltmann, Trinity, 94.

10 Moltmann, Trinity, 76-78.

11 John Wessel, De Causis Incarnationis, quoted in A.A. Hodge, Outlines of Theology (Grand Rapids: Zondervan, 1977 [orig. edn: London: Nelson, 1891]), 424.

12 We mean by this term the orthodoxy of post-Reformation scholasticism as outlined, e.g., in Heinrich Heppe, Reformed Dogmatics: Set Out and Illustrated from the Sources (tr. G.T. Thomson; London: Allen \& Unwin, 1950) and Heinrich Schmid, The Doctrinal Theology of the Evangelical Lutheran Church: 
although 'in him dwelleth all the fullness of the Godhead bodily' (Col. 2:9) so that 'I and my Father are one' (Jn. 10:30) and 'he that hath seen me hath seen the Father' (Jn. 14:9), yet the divine nature

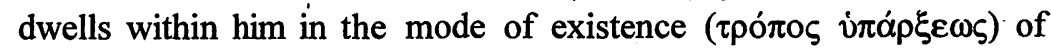
begottenness, not unbegottenness or procession (hence the distinction drawn, e.g., in Mt. 3:16-17 and Lk. 9:35). Because the Father, Son, and Holy Ghost differ only in their oppositions of relation, this distinction of aspect suffices to exclude the Father and Holy Ghost from personal union with Christ. ${ }^{13}$

Although Moltmann regards such a concept of God both modalistic ${ }^{14}$ and metaphysically untenable, ${ }^{15}$ it precludes entirely the criticism that an almighty Father butchers, or allows the butchering of, his helpless and tormented Son. Moltmann, by contrast, attempts to neutralise these complaints by attributing pain to the Father over the loss of his Son ${ }^{16}$ or by positing a concurrence of will on the Son's part to undergo suffering. ${ }^{17}$ The device of ascribing suffering to the Father over the anguish of his Son, however, founders out of sheer irrelevance. Whatever pain the Father might suffer from a crime, after all, cannot absolve him of the guilt of allowing it to occur.

Moltmann explicitly retreats in The Trinity and the Kingdom of God, moreover, from his earlier, correct, avowal of a 'deep community of will between Jesus and his God and Father...in the

Verified from the Original Sources (tr. Charles A. Hay \& Henry E. Jacobs; Philadelphia: Lutheran Publication Society, 1889).

13 Cf. Martin Chemnitz, The Two Natures in Christ (tr. J.A.O. Preus; St. Louis: Concordia, 1971), 39-44.

14 Moltmann, Trinity, 190. Ironically, Paul Molnar in his 'The Function of the Trinity in Moltmann's Ecological Doctrine of Creation', TS 51 (1990) 673-97, argues that Moltmann's doctrine of the Trinity, precisely because of its radically pluralistic character, approximates in some respects Schleiermachian modalism. He writes (697): 'The problem with this reasoning is that Moltmann believes he can speak about the trinitarian relations without speaking about the essential constitution of the Trinity as Father, Son, and Spirit by which we know of these relations. The only way this can be done is if the unity of the Trinity is conceived modalistically as a neutral fourth fellowship/relationship which can be appropriated apart from any specific reference to the Father, Son, or Spirit acting ad extra.'

15 Moltmann, Trinity, 18-19.

16 Moltmann, Crucified God, 243, 245, 247, 249. Moltmann, Trinity, 81. O'Donnell in his article, 'The Doctrine of the Trinity in Recent German Theology', HeyJ 23 (1982) 162, notes that Moltmann's insistence on the Father's suffering distinguishes his thought from that of other contemporary theologians (e.g. Jüngel and von Balthasar) who also speak of 'the Godforsakenness of the Son on the cross'.

17 Moltmann, Crucified God, 243-44. 
godforsaken and accursed death of Jesus on the cross'.18 Presumably in order to strengthen his case for divine passibility, Moltmann claims that Jesus begged his Father to deliver him from his suffering both in Gethsemane and on the cross and yet died abandoned and in despair. ${ }^{19}$ Such a claim ruins, of course, any attempt by Moltmann to vindicate the Father from the charge of imposing death on an innocent and unwilling Jesus. Yet even if Moltmann shunned inconsistency and maintained his earlier defence, i.e. that the Son freely co-operated in fulfilling the purpose of his Father, Moltmann would still attribute to the Father gross and inexcusable brutality. For Moltmann's Father would still impose a hideously painful death on an innocent, though willing, person.

Moltmann's doctrine of the Father, which he develops partly in order to construct a credible theodicy, therefore, fails precisely because it renders impossible any credible theodicy, and, arguably, engenders greater difficulties than the traditional doctrine which Moltmann seeks to replace. One may reasonably wonder, moreover, whether Moltmann's doctrine of the Father constitutes a doctrine of the Father (insofar as his never-ceasing begetting of the Son constitutes his Fatherhood) at all and not a doctrine of some other being. To clarify: Moltmann writes, in basically orthodox language (though we should prefer that he distinguish more clearly between

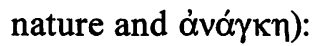

The generation and birth of the Son come from the Father's nature, not from his will. That is why we talk about the eternal generation and birth of the Son. The Father begets and bears the Son out of the necessity of his being. Consequently the Son, like the Father, belongs to the eternal constitution of the triune God. In Christian terms, no deity is conceivable without the eternal Father of the Son and without the eternal Son of the Father. ${ }^{20}$

\footnotetext{
18 Moltmann, Crucified God, 243-44. In adjudicating the problem of whether Christ suffered willingly or unwillingly on the cross, Moltmann faces a seemingly insoluble dilemma. If he claims that the Son suffers unwillingly, he implies that the Father imposes, or at least does not interfere with the death of an unwilling victim. If he claims that the Son willingly suffers, however, he diminishes Christ's solidarity with suffering humanity insofar as 'men simply have no choice in much of the suffering they undergo. Physical pain and death... usually occur as a result of what is done to us willy-nilly; things happen to humans without their consent' (D.G. Attfield, 'Can God Be Crucified: A Discussion of J. Moltmann', SJT 30 [1977] 48).

19 Moltmann, Trinity, 76-78.

20 Moltmann, Trinity, 167.
} 
Yet Moltmann also writes in the same work:

If we take the relinquishment of the Father's name in Jesus' death cry seriously, then this [the 'abandonment' of the Son in the crucifixion] is even the breakdown of the relationship that constitutes the very life of the Trinity: if the Father forsakes the Son, the Son does not merely lose his sonship. The Father loses his fatherhood as well. ${ }^{21}$

We know of only two ways to interpret these statements. Either a) Moltmann flatly contradicts himself, or b) Moltmann adheres to his principles of divine mutability and passibility so consistently that he considers no characteristic of deity, no matter how fundamental, invulnerable to change. The second construal, which we think more faithful to Moltmann's intent, reveals, first, perhaps the gravest and most obvious breach of orthodoxy by Moltmann's doctrine of the Trinity. Admittedly, Moltmann's relative indifference to concerns of orthodoxy22 decreases the significance of this discovery. If Moltmann does not shrink from denying the Trinity's numerical unity of essence (indeed, he denies the existence of a divine 'essence'), why should we be surprised if he denies the eternal Fatherhood of the Father ${ }^{23}$ as well?

Second, and more importantly, Moltmann's denial of the eternity of the Father-Son relationship in God (which necessarily follows from his claim that the Son, in his divine nature, temporarily dies) exposes the vapidity of Moltmann's claim that a denial of the ontological immutability of God need not involve a denial of his ethical immutability as well. ${ }^{24}$ If events of salvation history can 'suspend', as it were, the very existence of the holy Trinity, presumably they could suspend, perhaps permanently, the working of any other aspect of the deity. ${ }^{25}$ Moltmann's doctrine of the

21 Moltmann, Trinity, 80.

22 Moltmann in his 'Foreword' to Richard Bauckham's Moltmann: Messianic Theology in the Making (Basingstoke: Marshall, Morgan and Scott, 1987), viii, characterises his work as 'theological thinking without the security of tradition, dogma or authorities...a risky and adventurous undertaking.' $\mathrm{Cf}$. the remarks of Richard Clutterbuck, 'Jürgen Moltmann as a Doctrinal Theologian: The Nature of Doctrine and the Possibilities for Its Development', SJT 48 (1995) 489-98.

${ }^{23}$ Such a denial, of course implies a denial of the eternity of the Trinity. Moltmann's statement (Trinity, 80) that, temporarily, 'not only does the Son lose his sonship. The Father loses his fatherhood as well', entails, as Moltmann admits, 'the breakdown of the relationship that constitutes the very life of the Trinity'.

${ }^{24}$ Moltmann, Crucified God, 285. Cf. Thomas Weinandy, Does God Suffer? (Edinburgh: T \& T Clark, 2000), 161-62.

25 Some less radical passibilist theologians (e.g. Jean Galot), of course, attempt to avert this consequence by excluding the suffering which God experiences 'for 
Father, therefore, impugns both the triunity and the trustworthiness of the Christian God.

\section{The Son as Exemplar of Divine Suffering?}

These difficulties, as we shall see, manifest themselves no less in Moltmann's doctrine of the Son, the central elements of which include Moltmann's sharp denial of the Son's impassibility and a sustained polemic against the Chalcedonian doctrine of Christ's two natures. The first major plank of Moltmann's Christology, his denial of the Son's impassibility, figures prominently in Moltmann's theodicy. According to Moltmann, such divine fellow-suffering constitutes the only possible way to vindicate God from the charge of cruelty and console grieving humanity without at the same time justifying and thus perpetuating the injustices at the root of human grief. ${ }^{26}$ This approach of Moltmann possesses at least one outstanding merit. He correctly perceives that suffering persons derive comfort from the compassion of others. Moltmann founds his theodicy, therefore, on an indisputably valid psychological principle. Yet Moltmann's concern for a plausible theodicy fails to warrant his insistence on divine passibility, most dramatically illustrated in the crucifixion of the Son, for two reasons.

First, any theodicy which depends on the axiom of divine passibility undermines the Christian's legitimate confidence in the righteousness and promises of God. For consistency requires that if we deny God's impassibility, we must also deny his ontological immutability, and, if we deny his ontological immutability, we must deny his ethical immutability as well. God's faithfulness, after all, a single property of the divine nature, guarantees nothing if we subject the divine nature itself to infinite variability (as Moltmann does by affirming that, in his divine nature, the second Person of the Trinity can die). Moltmann's God, therefore, could never strengthen the suffering Christian with an infallible hope of deliverance.

us' from a supposed inner life of God in which he remains impassible and immutable. Such a defense founders, however, on the simplicity of God. If God is, indeed, simple (and we see no other way to account for the biblically attested identity of his essence with the attributes, e.g. of love, truth, and life), then any change in a single aspect of God's life must constitute a change in every aspect of God's life.

26 Moltmann, Crucified God, 276-78. 
Second, Moltmann's theodicy does not begin to address the depths of the problem of evil. Even if one granted that God loves humanity with an infinite love and that he suffers in solidarity with his creatures, what would one thereby gain? A mere human being can suffer in solidarity with his fellow creatures. But God presumably possesses the power not only to eliminate, but to prevent the very occurrence of evil. Why does he not exercise this power and if he, in fact, does not possess such power, why should the church worship him? Moltmann's theodicy barely begins to address these dilemmas.

We have shown, therefore, that Moltmann's theodicy fails to refute key elements of the case for protest atheism by appealing to a supposed divine passibility. But, a passibilist might respond, even if Moltmann has not comprehensively refuted the charges of protest atheism, has he not proved that we cannot mount a successful case against protest atheism without including the postulate of divine passibility as a central component?

To this we reply that he certainly has not. For Moltmann's arguments for divine benevolence from divine suffering appeal exclusively to the protest atheist's feelings. If a blind man learns that God pities him, that God not only has not caused his suffering, but grieves with him in all his struggles, the blind man very well may cease to resent God. But none of this will make him see. The brute fact of evil in a world, if not governed, then at least governable, by God remains an unsolved and apparently insoluble difficulty for Christian belief from the perspective of the protest atheist's reason. Moltmann's musings about divine passibility contribute nothing to resolving this dilemma. He fails, therefore, to prove divine passibility necessary to any credible theodicy.

Moltmann by no means, however, restricts his case for divine passibility to the realm of theodicy. He also proposes a speculative argument (of sorts) on the basis of an analysis of human love. With great frequency throughout The Crucified God and The Trinity and the Kingdom of God Moltmann repeats variants of the following statement:

...a God who cannot suffer is poorer than any man. For a God who is incapable of suffering is a being who cannot be involved....He is so completely insensitive [that] he cannot be affected or shaken by anything. He cannot weep, for he has no tears. But the one who cannot suffer cannot love either. So he is a loveless being. Aristotle's God cannot love....A God who is only omnipotent is in himself an incomplete being, for he cannot experience helplessness and powerlessness....A man who experiences helplessness, a man who suffers because he loves, a man who can die, is therefore a richer being than an omnipotent God who 
cannot suffer, cannot love, and cannot die. Therefore, for a man who is aware of the riches of his own nature in his love, his suffering, his protest and his freedom, such a God is not a necessary and supreme being, but a highly dispensable and superfluous being. ${ }^{27}$

Moltmann's harsh assessment of the traditional concept of God seems to rest on a twofold error. First, Moltmann seems to think that God's inability to suffer, weep, and die, to experience 'helplessness and powerlessness' somehow constitutes a defect in God's being, an impotent omnipotence, as it were. Like the late medieval nominalists, therefore, Moltmann ascribes apparent weaknesses to God in order to endow him with a different and, in Moltmann's opinion, more meaningful, kind of strength. He thus commits himself to a common though, we believe, mistaken answer to a classical dilemma. Anselm of Canterbury formulates the problem in the following way:

...How art thou [O God] omnipotent, if thou art not capable of all things? Or if thou canst not be corrupted, and canst not lie, nor make what is true, false - as, for example, if thou shouldst make what has been done not to have been done, and the like-how art thou capable of all things? ${ }^{28}$

Anselm plainly raises a problem very similar to that faced by Moltmann. Anselm's response to it, however, radically differs. He writes:

...to be capable of these things [i.e. the things referred to above] is not power but impotence. For, he who is capable of these things is capable of what is not for his good, and of what he ought not to do; and the more capable of them he is, the more power have adversity and perversity against him; and the less has he himself against these. He, then, who is thus capable is so not by power, but by impotence.... Therefore, $\mathrm{O}$ Lord, our God, the more truly art thou omnipotent, since thou art capable of nothing through impotence, and nothing has power against thee. ${ }^{29}$

In refusing to attribute to God the power to die, to suffer, and to weep, we deny him no genuine privilege; he lacks nothing but lack. Yet, in resolving this dilemma, we have not touched the heart of Moltmann's speculative argument for divine passibility. Although Moltmann's criticism of the traditional doctrine of divine impassibility bears important similarities to that of the nominalist criticisms based on their expansive concept of divine omnipotence, Moltmann by no means wishes to introduce the idea of a divine

27 Moltmann, Crucified God, 222-23.

28 Proslogium 7 in St. Anselm: Basic Writings (tr. Sidney N. Deane; LaSalle, IL: Open Court, 1962), 12.

29 Proslogium 12-13. 
potentia absoluta. In fact, he specifically rejects such a theory as a relic of the 'Roman law of property' which 'is hardly appropriate for the God who is love'. ${ }^{30}$ 'Freedom,' according to Moltmann, 'arrives at its divine truth through love', ${ }^{31}$ which he describes as 'a selfevident, unquestionable "overflowing of goodness" which is never open to choice at any time.' 32 Moltmann does not, therefore, object to divine impassibility out of concern for an abstract theory of divine omnipotence. He objects to the traditional doctrine, because he regards suffering as indispensable element of any true love.

'In order to be completely itself, love has to suffer.' ${ }^{33}$ Insofar as Moltmann speaks of mortal, human love here few will contradict him. Even Anselm agrees. Addressing God, he writes, 'If thou art passionless, thou dost not feel sympathy; and if thou dost not feel sympathy, thy heart is not wretched from sympathy for the wretched; but this it is to be compassionate. ${ }^{34}$ Likewise, few would dispute Moltmann's insistence on the centrality of love to the being of God (1 Jn. 4:16). 'For the loving worm within its clod/ were diviner than a loveless God.' ${ }^{35}$

Only when Moltmann reasons from the major premise, 'All love involves suffering', and the minor premise, 'God is love', to the verdict 'God suffers', does he meet serious disagreement and this for two reasons. First, the consequence Moltmann draws, that God suffers, undermines God's ontological and, therefore, his ethical immutability. As we have shown, he who worships a changeable God, worships an unreliable God. Moltmann's thesis thus undermines the belief of the Bible and the people of God in all ages, a fatal flaw for any argument in Christian theology.

Second, Moltmann's argument rests on an unproved and probably unprovable major premise: that divine love as well as human love involves suffering. In view of Moltmann's failure explicitly to argue for this claim, which he apparently considers selfevident, one might easily reply: gratis asseritur, gratis negatur. The popularity of this idea among passibilist theologians, ${ }^{36}$ however, and

\footnotetext{
30 Moltmann, Trinity, 54.

31 Moltmann, Trinity, 55.

32 Moltmann, Trinity, 55.

33 Moltmann, Trinity, 33.

34 Proslogium 8 in Basic Writings, 13.

35 Robert Browning, Christmas Eve V, 23-25 quoted in Moltmann, Trinity, 38.

36 Thomas Weinandy (Does God Suffer?, 94), before offering a critique of this idea similar to our own, describes the idea 'that for God to be impassible means
} 
the genuine (though, in our opinion, seductive) appeal of Moltmann's frequently poetic language on the subject demand a more detailed response.

Moltmann describes the impassible God of classical theism as 'incapable of feeling, as is the case with dead things', ${ }^{37}$ and considers the nature of a man who per impossibile finds himself in such a state. '...A man can suffer because he can love, even as a Narcissus, and he always suffers only to the degree that he loves. If he kills all love in himself [however], he no longer suffers. He becomes apathic. But in that case is he a God? Is he not rather a stone?'38 From this thought experiment emerges the root of Moltmann's understanding of the reciprocality of divine love and suffering. ${ }^{39}$ Impassibility, for Moltmann, makes God indifferent, heartless, unconcerned, aloof: not the biblical God of love, but a stone.

This impassible God, however, bears no resemblance to the equally, indeed, perhaps more so, impassible God proclaimed by the medieval scholastics and the Fathers of the Church. ${ }^{40}$ Their God never suffers not because he never loves nor hates nor feels nor cares, but because he never fails in the slightest to remain in pure act. In depicting God as impassible, they do not mean to say that a sinner does not incur his anger. They mean, instead, that before the sinner betrays his God and for all eternity, nothing can detract from the white heat of that anger. Likewise, the Fathers do not mean to say that the suffering of God's saints does not move him to compassion. They mean to say that even before the suffering and for all eternity afterward, God burns with the flames of infinite, incomprehensible, ineffable love.

that he is unloving' as a 'common mistake made by many contemporary critics of God's impassibility'.

37 Moltmann, Crucified God, 267.

38 Moltmann, Crucified God, 222.

39 Marc Steen, in his article, 'Jürgen Moltmann's Critical Reception of K. Barth's Theopaschitism', EThL 67 (1991) 307, aptly criticises Moltmann's anthropomorphism: 'That God's love ipso facto implies suffering, is an unfounded assertion, which issues from a modern, perilous urge to impose on God as ratio essendi our finite human experiences of love.' Richard Bauckham, in his " Only the Suffering God Can Help": Divine Passibility in Modern Theology', Themelios 9 (1984) 10, inadvertently verifies Steen's criticism. He writes: 'In modern theology, it has often been said that if God is personal love, analogous to human personal love, then he must be open to the suffering which a relationship of love can bring.'

40 Weinandy, Does God Suffer?, 83-146. 
The Christian need not, therefore, provoke suffering or change in God in order to receive divine mercy. 'For your Father knoweth what things ye have need of before ye ask him' (Mt. 6:8). Indeed, God shows mercy to those who do not love him (Rom. 5:10, 8:7; Col. 1:21), who do not fear him (Rom. 3:18), who do not seek him (Rom. 3:11), of whom 'there is none that doeth good, no, not one' (Rom. 3:12) 'For when we were yet without strength, in due time Christ died for the ungodly' (Rom. 5:6). Even when the regenerate betray him, moreover, despising the mercy of him who saved them 'as a firebrand plucked out of the burning' (Am. 4:11; cf. Zec. 3:2), God remains faithful. 'I am the Lord, I change not; therefore ye sons of Jacob are not consumed' (Mal. 3:6). Moltmann's refusal to acknowledge divine love apart from divine suffering, therefore, rests on a fundamental misunderstanding. His speculative concept of love fails to do justice to the intensity of divine love and in no way compels acceptance of suffering in the deity.

Moltmann crowns his argument for divine passibility, especially in the Person of the Son, by appealing to Jesus' cry of dereliction: 'Eli, Eli, lama sabachthani? that is to say, My God, my God, why hast thou forsaken me?' (Mt. 27:46; Mk. 15:34; cf. Ps. 22:1) According to Moltmann, this prayer:

must surely be the very kernel of the Golgotha story, historically speaking; for the notion that the Saviour's last words to God his Father could possibly have been this cry of despair could never have taken root in the Christian faith if it had never been uttered, or if the despair had not at least been perceptible in Christ's death cry. 41

Moltmann takes the cry of dereliction (which he, not uncontroversially, interprets as a 'cry of despair') to mean that Christ 'was not merely assailed by fear and suffering in his human nature, as scholastic tradition would have it. He was assailed in his person, his very essence, in his relationship to the Father-in his divine sonship.' 42 Moltmann clings to this construal of Christ's words in spite of Christ's other sayings on the cross, which, as Moltmann recognises, convey a sense of 'comfort and triumph'. 43

Moltmann confesses that Luke ascribes to the crucified Christ 'the confident utterance of the Jewish evening prayer from Ps. 31.6: "Father, into thy hands I commit my spirit" (23.46). ${ }^{44}$ Moltmann

41 Moltmann, Trinity, 78.

42 Moltmann, Trinity, 77.

43 Moltmann, Crucified God, 146.

44 Moltmann, Crucified God, 147. 
likewise admits that "in John...we read: "It is finished" (19.30), since for John Jesus' struggle ends with his victory and glorification on the cross.' 45 Moltmann even admits that 'to complete the paradox [sic], in Mark the Gentile centurion responds to the cry with which Jesus breathes his last by professing that Jesus is the Son of God: "Truly this man was the Son of God" (15.39) [cf. Mat 27:54].'46

Moltmann also could include among these Christ's words: 'Father, forgive them; for they know not what they do' (Lk. 23:34); 'Verily I say unto thee, Today shalt thou be with me in paradise' (Lk. 23:43); and Christ's words to John: 'Behold thy mother' (Jn. 19:27); as well as Christ's words to Mary: 'Woman, behold thy son' (Jn. 19:26). Why then, in defiance of the Evangelists' intent to portray not only Christ's agony, but also his strength on the cross, does Moltmann insist on treating the cry of dereliction as a 'cry of despair'?

Moltmann, it seems, regards any New Testament text which reeks of 'the God of empires and rulers...enthroned in heaven'47 as inauthentic and destructive. Texts which exalt "the "God" of the poor, the peasant and the slave [who] has always been the poor, suffering, unprotected Christ', ${ }^{48}$ by contrast, he exploits to advance his theological program. For Moltmann 'truth is revolutionary'. ${ }^{49}$ Those passages which affirm Christ's supernatural character even when on the cross and thus diminish his solidarity with suffering mankind Moltmann summarily dismisses. They do not convey his message.

Moltmann distrusts, moreover, not only the early church, but even the Bible as a source of data about Christ's death. Accordingly, he holds that 'the history of the tradition shows that the horror and shock that emanates from it [i.e. Christ's cry of dereliction] was later softened down, and the saying was replaced by more pious parting words.' ${ }^{50}$ Since the biblical writers (or, at least, the later ones) intend to deceive, Moltmann seems to think, their very denials that Christ despaired constitute evidence that he did. In true dialectical fashion, Moltmann claims that precisely because the Gospel accounts

\footnotetext{
45 Moltmann, Crucified God, 147.

46 Moltmann, Crucified God, 147.

47 Moltmann, Crucified God, 45-46.

48 Moltmann, Crucified God, 45.

49 Moltmann quotes approvingly these words of Gramsci on pp. 132 and 139 of his Religion, Revolution, and the Future (tr. M. Douglas Meeks; New York: Scribner's, 1969).

50 Moltmann, Trinity, 78.
} 
contain 'words of comfort and triumph, we can probably rely upon it [i.e. the supposed cry of despair] as a kernel of historical truth. ${ }^{51}$

Moltmann's historical case for Christ's despair rests, therefore, on the Evangelists' presumed dishonesty: if the memory of Christ's 'cry of despair' had not ineffaceably emblazoned itself on the communal memory, they would surely have omitted it altogether. Such a verdict cannot, however, withstand scrutiny. The Gospels themselves undermine it by their overwhelming testimony to their authors' honesty. The Evangelists, Moltmann seems to assume, glossed over, whenever possible, events of Christ's life they deemed scandalous or inconvenient. Yet they related the apostasy, betrayal, and terrible end of Judas, one of the original twelve apostles. It seems such a fact would have proved profoundly inconvenient for a fledgling church 'built upon the foundation of the apostles' (Eph. 2:20).

Moltmann could, of course, argue that this episode too had engraved itself indelibly on the church's memory. But he could not plausibly assert this of Christ's conversing with the Samaritan woman at the well (Jn. 4:7-26); of Christ's immediate family's unbelief (Jn. 7:5); of the prominence among Christ's followers of Mary Magdalene (Lk. 8:2, 3); of Christ's being kissed and anointed by sinful women (Mt. 26:7; Mk. 14:3-9; Lk. 7:37-38); of Christ's (seemingly false) statement that 'I go not up yet unto this feast' (Jn. 7:8); of Christ's childhood growth 'in wisdom and stature, and in favour with God and man' (Lk. 2:52); or of Christ's embarrassing prophecies that 'there be some standing here which shall not taste of death, till they see the Son of man coming in his kingdom' (Mt. 16:28; Mk. 9:1; Lk. 9:27) and 'this generation shall not pass away, till until be fulfilled' (Mt. 24:34; Mk. 13:30; Lk. 21:32). The Evangelists, in short, seem simply to tell the truth without worrying about whether their accounts might prove 'inconvenient'. Moltmann's challenge, therefore, to the historicity of the less alarming words of Christ on the cross, resting as it does on the Evangelists' dishonesty, stands, at best, unproved.

The words in dispute, moreover, Eli, Eli, lama sabachthani, admit of a construal which does not convey despair and which coheres perfectly with the crucified Christ's other statements.

In the Jewish tradition up to this day, the books of the Pentateuch, or weekly portions of it, or some prayers, are cited by the first major word

51 Moltmann, Crucified God, 146. 
or sentence. Some psalms are also still cited by the first words or sentence. For instance Ashrei (Psalm 1), or Al naharot Bavel (Psalm 137). It is likely that at the time of the first Gospels, Psalm 22, in analogy to this usage, was also cited by its first major sentence. In other words, the Gospel tells us that Jesus, when he was dying, recited Psalm 22. This being so, there is no problem to be solved. As we have seen, the psalm begins in despair, but it ends in an enthusiastic mood of faith and hope. ${ }^{52}$

\section{One Person, One Nature?}

The words Christ uttered on the cross, Eli, Eli, lama sabachthani, in no sense, therefore, prove that the divine nature suffered. Indeed, even if per impossibile Christ had undergone actual despair, this would not necessarily imply passibility in God. One could always confine the suffering to Christ's human nature. Moltmann, therefore, devotes great effort to proving that Christ possesses only one nature so that one may not preserve the immutability, impassibility, or transcendence of God with reduplicative formulas like 'passible in His flesh, impassible in His Godhead'.53 Moltmann wishes to establish that:

Humiliation to the point of death on the cross corresponds with God's nature in the contradiction of abandonment. When the crucified Jesus is called the 'image of the invisible God,' the meaning is that this is God, that God is like this. God is not greater than he is in this humiliation. God is not more glorious than he is in this self-surrender. God is not more powerful than he is in this helplessness. God is not more divine than he is in this humanity. The nucleus of everything that Christian theology says about 'God' is to be found in this Christ event. ${ }^{54}$

For Moltmann, therefore, Christ must constitute the deus revelatus and not the deus absconditus. With this end in view, he proposes three principal arguments against Chalcedonian orthodoxy. First, Moltmann contends:

If the eternal Logos assumed a non-personal human nature, he cannot then be viewed as a historical person, and we cannot talk about 'Jesus of Nazareth.' The human nature that was assumed would then seem to be like the human garment of the eternal Son-something which he put on

52 Erich Fromm, You shall be as gods: A radical interpretation of the Old Testament and its tradition (London: Jonathan Cape, 1967), 232.

53 Gregory of Nazianzus, Ep. 101 ad Cledonium quoted in J.K. Mozley, The Impassibility of God: A Survey of Christian Thought (Cambridge: CUP, 1926), 87.

54 Moltmann, Crucified God, 205. 
while he walked on earth. It becomes difficult to find an identity here between this human nature and our own. 55

We find this argument wanting for two reasons. First, in judging any nature with a divine hypostasis necessarily inhuman, Moltmann assumes: a) that a static and definable 'essence' of humanity exists; and b) that, independently of God's revelation of the nature of true humanity in Christ, he, Moltmann, understands this nature sufficiently to declare someone inhuman. Both premises conflict with Moltmann's published statements about human nature. In Hope and Planning, Moltmann writes: "Mankind"-the realized generic concept-is becoming, is still in process, has not yet acquired a fixed "nature." 56 Moltmann lacks, therefore, a theoretical basis for excluding the Christ of Chalcedon from the class of humanity. Moltmann holds, moreover, that even to the extent that man does possess such an essence as 'an anticipated eschaton of history', ${ }^{57}$ he cannot yet know it. 'His essence is not handed to him as a finished product but assigned to him as a task. Thus he is hidden to himself and constantly in search of his true essence.' 58 Moltmann's argument from the nature of humanity thus fails through simple inconsistency.

Even if Moltmann did consistently claim that a knowable and static human essence existed, furthermore, his argument would still prove invalid. For Moltmann commits the elementary error of confusing universal with essential properties of human nature..$^{59}$ Every human being heretofore, for instance, has commenced his existence on the planet Earth. Here we have a universal property of human beings. Yet, given the development of space travel, a human being could easily be conceived on the moon or Mars in the near future. ${ }^{60}$ Even though the baby would lack a property possessed by every other person who ever existed, he would remain a human being nonetheless, because 'commencing life on the earth' constitutes not an essential, but only a (previously) universal property of human

55 Moltmann, The Way of Jesus Christ: Christology in Messianic Dimensions (tr. Margaret Kohl; London: SCM, 1990), 51.

56 Moltmann, Hope and Planning (tr. Margaret Clarkson; London: SCM, 1971), 80.

57 Moltmann, Hope and Planning, 81.

58 Moltmann, The Experiment Hope (tr. M. Douglas Meeks; London: SCM, 1975), 20.

59 Cf. Thomas V. Morris, The Logic of God Incarnate (Ithaca, NY: Cornell University, 1986), 62-63.

60 We owe this example to Morris, The Logic of God Incarnate, 63. 
beings. Likewise, if, as Christians, we recognise in Christ the most perfect exemplar of God's design for humanity, ${ }^{61}$ we must conclude that the property of possessing a uniquely human hypostasis, even though universal among human beings before the Incarnation, cannot count as essential to humanity. That the eternal Logos, and not a merely human hypostasis, enhypostasises Christ's human nature by no means renders that nature alien to our own.

Moltmann's second argument against traditional two-natures Christology, similarly, rests on two fundamental errors. Moltmann contends that:

If the eternal Logos has assumed a human nature without sin, then he is immortal not merely in his divine nature but in his human nature too, since mortality is a consequence of $\sin$. But if he assumed a human nature which was in itself immortal, then this cannot actually have been born either; for what is immortal has neither birth nor death....Both the divine personal centre and the inherently immortal body of Christ must then be pre-existent and must have entered into Mary out of eternity.... [Furthermore] if the God-human being is in essence immortal not only in his divine nature but in his human nature too, in which capacity did Christ then die?62

These claims by Moltmann manifest, first, enormous misunderstanding of the kind of 'immortality' entailed by the sinlessness of the first human beings. God created Adam and Eve sinless and, therefore, not necessarily subject to the penalty of sin, death. They possessed immortality in the sense that they need not have died, i.e. they could have persisted in righteousness and, through the covenant of works, obtained eternal life. They did not, however, possess immortality in the sense that they could not die, a state which the Church will attain only at the general resurrection. Adam and Eve certainly did not, moreover, possess immortality in the sense that God possesses immortality; i.e. they lacked the necessary self-existence which makes it inconceivable for God either to come to be or to die.

Even if one accepted Moltmann's premise, therefore, that Christ's sinlessness necessarily entails his immortality, it would not follow that Christ could not have died. It would merely follow that he need not have died, though, of course, he did. The orthodox, however, do not accept Moltmann's premise. As Chemnitz explains:

...Because Christ was conceived by the Holy Ghost, He assumed a human nature without sin and incorrupt. Therefore, those infirmities which are

61 Moltmann, Trinity, 116; Morris, The Logic of God Incarnate, 64.

62 Moltmann, Way, 51-52. 
the consequent penalties of sin were not to be in Christ by the necessity of his condition, but His body could be free from those weaknesses and need not be subject to them....But for us and for our salvation the incarnate Christ willingly assumed the infirmities by which our nature was burdened as a necessary condition because of $\sin$, in order that He might commend to us His love, that He thereby might take away from us the penalty which fell upon Himself and free us from it, and thus be made the victim for our sins....63

The physical infirmities of Christ, therefore, show forth the depth of his compassion for sinners, not the presence of any moral imperfection in his own spotless, human nature. Their prerequisite is love, not sin. In any event, no biblical passage and no traditional standard of doctrine has ever affirmed that Christ's human nature existed from all eternity or that Christ's human nature, before the Resurrection, possessed a spiritual body that could not die. Moltmann's complaint based on Christ's 'immortality', therefore, appears profoundly misguided.

Moltmann's third argument against Chalcedonian Christology, that Christ's suffering and human experience become less 'real' if one assumes Christ possesses a divine nature and a divine hypostasis, repeats and intensifies the error of his first argument: i.e. the idea that simply because Christ lacks properties characteristic of all other persons (and possesses properties which they lack), he cannot constitute a human being. The third argument supplements this error with the hypothesis that Christ could not have fully experienced human life and the agonies of his death on the cross unless he experienced them in every aspect of his nature(s).

Such a scenario would imply, however, one of two unacceptable consequences. Either Christ's suffering would become inhuman because experienced by a mongrel, divine-human nature, ${ }^{64}$ or God's nature (to the extent that, according to Moltmann, he possesses one $^{65}$ ) would become identical with the human nature of Jesus Christ. In fact, Moltmann seems to accept the second consequence as a legitimate finding of Christian theology. But he does so at the risk of imperilling the historicity of the resurrection and the ability of his God to inspire hope in the afflicted.

Such a divine-human identity would cast doubt upon the resurrection, because if in his essence, and thus not only as Son, but

63 Chemnitz, Two Natures, 53.

64 Weinandy, Does God Suffer?, 204.

65 Roland Zimany, in his 'Moltmann's Crucified God', Dialog 16 (1977) 51, points out that Moltmann frequently seems to contravene his own strictures against essentialist modes of thinking. 
also as Father and Holy Spirit, 'God is not more powerful than he is in this helplessness [i.e. the cross]' 66 and 'not more divine than he is in this humanity [i.e. the crucified Jesus]', 67 he presumably could not raise anyone, including himself, from the dead. Neither could such an effete God inspire the vigorous social and political activism which Moltmann regards as indispensable to the church's relevance and even her survival in contemporary society. 68 Moltmann's denial of the presence of distinct divine and human natures in Christ, therefore, meets neither the truth criteria nor what Moltmann regards as the needs of contemporary Christian theology. In the light of our previous findings, moreover, we can justly extend this verdict to the whole of Moltmann's staurological Christology.

\section{The Spirit as Dispensable Accessory?}

Moltmann's doctrine of the Holy Spirit, as we shall see, fares little better. Moltmann's pervasive indifference to concerns of orthodoxy, ${ }^{69}$ of course, makes finding a criterion acceptable to Moltmann on which to base an immanent critique of his pneumatology quite difficult. In at least one area, however, Moltmann violates principles he has laid down elsewhere as fundamental to an authentically Christian theology. In spite of his insistence on the distinct subjecthood of each of the three Persons of the Trinity, Moltmann ascribes to the Holy Spirit no role in the cross/resurrection event which requires the act of a distinct subject. He fails to meet the criteria for a genuinely Trinitarian pneumatology which he applies to the 'reflection Trinity' of Barth. According to Moltmann, the God of Barth cannot:

display subjectivity in...the Holy Spirit. The Spirit is merely the common bond of love linking the Father with the Son. He is 'the power that joins the Father and the Son.' But this bond is already given with the relationship of the Father to his beloved Son and vice versa. The Father and the Son are already one in their relationship to one another, the relationship of eternal generation and eternal self-giving. In order to think of their mutual relationship as love, there is no need for a third Person in the Trinity. If the Spirit is termed the unity of what is

66 Moltmann, Crucified God, 205.

67 Moltmann, Crucified God, 205.

68 Moltmann, Religion, 108, 128, 133-34.

69 Cf. n. 22 above. 
separated, then he loses every centre of activity. He is then an energy but not a Person. He is then a relationship but not a subject. ${ }^{70}$

Moltmann similarly characterises the Holy Spirit as God's light, his power, and his empathy, 'Yahweh's ruach, the divine energy of life'. ${ }^{71}$ But do the Father and the Son not possess light, power, empathy, and light? Admittedly, Moltmann does conceive of the Holy Spirit as the auctor resurrectionis. ${ }^{72}$ Yet he in no way indicates how, as auctor resurrectionis, the Holy Spirit performs anything not easily within the power of the Father. ${ }^{73}$ Unlike the Son, without whom the Father could not pour out his wrath on an innocent divine victim thus reconciling the world to himself, the Spirit merely returns to the Father the Son thus securing the unity of the two in much the same way as Augustine's vinculum amoris. ${ }^{74}$ Although Moltmann attributes to the Spirit an extensive role in other aspects of the economy of salvation, Moltmann's Spirit cannot constitute a subject if we seek to derive our pneumatology solely from 'the event of the cross' 75 which Moltmann considers 'the shortest expression of the doctrine of the Trinity' ${ }^{76}$ Insofar as 'the theology of the Trinity must be the theology of the cross', ${ }^{77}$ Moltmann's 'approach provides no justification for the Holy Spirit's independent existence as Person in the Trinity'. ${ }^{78}$

\section{Conclusion}

It seems, therefore, that Moltmann's attempt to derive a doctrine of the Trinity faithful to the Bible and the legitimate concerns of tradition yet entirely based on 'the event of the cross' 79 fails. By this

70 Moltmann, Trinity, 142.

71 Moltmann, The Spirit of Life: A Universal Affirmation (tr. Margaret Kohl; London: SCM, 1992), 66.

72 Moltmann, The Spirit of Life, 67.

73 Carl Braaten writes in his 'A Trinitarian Theology of the Cross', JR 56 (1976) 118, of the theology of The Crucified God: 'Whereas the relations between the Father and the Son are spelled out in the event of the cross, the Spirit goes along for a free ride. Would not a binitarian concept of God work as well?'

74 Cf. Moltmann, Trinity, 143.

75 Moltmann, Crucified God, 205, 245.

76 Moltmann, Crucified God, 241.

77 Moltmann, Crucified God, 241.

78 Moltmann applies these words to Barth's doctrine of the Trinity in Trinity, 143.

79 Moltmann, Crucified God, 205, 245. 
verdict we do not mean to condemn Moltmann's theology of the cross or his doctrine of the Trinity in every respect. If one abstracts from his, in our opinion, misguided attempt to relate the theology of the Trinity to the theology of the cross, one can truthfully credit him with a considerable degree of success in at least one area.

Moltmann, to a great extent correctly, recognises a mutual interdependence between human hope and suffering. 'Hope and planning,' Moltmann writes, 'have their foundation in suffering and dissatisfaction with the present. ' 80 Yet only 'at the moment when the new awakens hope...[are] suffering and dissatisfaction...born.' ${ }^{21}$ Unlike Moltmann's reveries about passibility in God, this psychological discovery does seem to provide real comfort for a person in misery. If the person cherishes his hope sufficiently, he can bear his sufferings as hope's exorbitant, but inescapable price. If the hope proves unrealistic or unworthy, however, the person can suppress his hope and thereby diminish the pangs of his suffering. ${ }^{82}$

This mutuality between hope and suffering, which Moltmann sees as epitomised in the dialectic between resurrection and cross, ${ }^{83}$ constitutes an important psychological, but not theological, insight. Moltmann's theology bears meagre fruit from the perspective of Christendom as a whole because of his marked selectivity in the use of biblical revelation which remains normative, in some sense at least, for every Christian church. 'We shall take our bearings,' Moltmann writes in describing his theological methodology, 'from the following guideline. We shall work out what in the text furthers life, and we shall subject to criticism whatever is hostile to life. ${ }^{84}$ To this rule, which Moltmann interprets according to his stridently leftist world-view, Moltmann adds the requirement that:

Christian theology must show how far the Christian confession of faith in Jesus is true as seen from the outside, and must demonstrate that it is relevant to the present-day understanding of reality and the present-day dispute about the truth of God and the righteousness of man and the world. ${ }^{85}$

\footnotetext{
80 Moltmann, Hope and Planning, 178.

81 Moltmann, Hope and Planning, 182.

82 Moltmann, however, emphatically opposes such a use of his theory. He writes, for instance in The Experiment Hope, 89: 'To live without hope is to cease to live.'

83 Moltmann, Hope and Planning, 42-50, 170-74.

84 Moltmann, Experiences in Theology (London: SCM, 2000), 149.

85 Moltmann, Crucified God, 84.
} 
All of these criteria leave the Bible little room to speak for itself according to the world-view of its own time and as a whole. If Moltmann allowed the Bible to speak for itself instead of attempting to 'spin the whole of theology out a single principle', ${ }^{86}$ he would have to reconcile his doctrine of the Trinity with the biblical testimony to man's insignificance in the eyes of God (e.g. Is. 40:15, 17; Dn. 4:35), the sovereignty, omnipotence, and immutability of God, and, above all, the absolute and uncompromisable unity of God. ${ }^{87}$ Moltmann's current methodology, however, allows him not only to neglect, but actually to defy such important biblical principles. That he cannot develop a satisfactory doctrine of the Trinity with his current method follows as a matter of course. His Trinitarian theology fails because of his excessively narrow perspective.

${ }^{86}$ Carl Braaten, 'A Trinitarian...', 120. According to Braaten (120), the theology of The Crucified God suffers from 'the tyranny of the single category'.

87 Richard J. Neuhaus, in his article 'Moltmann vs. Monotheism', Dialog 20 (1981) 239-43 sharply criticises Moltmann for his disavowal of monotheism. Even the very sympathetic Ted Peters, in his 'Moltmann and the Way of the Trinity', Dialog 31 (1992) 277-78, agrees that Moltmann fails to do justice to the divine unity; and George Hunsinger ('The Crucified God and the Political Theology of Violence I', HeyJ 14 [1973] 278), John Milbank ('The Second Difference: For a Trinitarianism Without Reserve', Modern Theology 2 [1986] 223), and John O'Donnell ('The Trinity as Divine Community', Greg 69 [1988] 21) all concur in this verdict. 